\title{
ARTIFICIAL VENTILATION IN INFANTS AND YOUNG CHILDREN USING A NEW VENTILATOR WITH THE T-PIECE*
}

\author{
Shigeo Kuwabara, M.D., and Thomas J. McCaughey, M.B., B.Ch. $\dagger$
}

Most ANAESTHETISTS use some modification of the T-piece technique with endotracheal intubation for infants and small children. The principles have been clearly defined for spontaneous respiration by Mapleson, ${ }^{1}$ but there is very little in the literature on the performance of this system with controlled respiration, which is far more commonly indicated, particularly in the infant. The work of Harrison $^{2}$ on an experimental model, and the findings of Nightingale, Richards, and Glass ${ }^{3}$ on another modification of the T-piece are certainly useful contributions. The Jackson Rees' modification (Fig. 1) has gone unassessed so far, though it is very commonly used because of the greater flexibility and the "feel" it imparts to controlled respiration.

The search for a suitable respirator for neonatal anaesthesia which retains the simplicity of the T-piece has been frustrating. Each anaesthetist has his own criteria, but most would demand that such a device should retain a good deal of

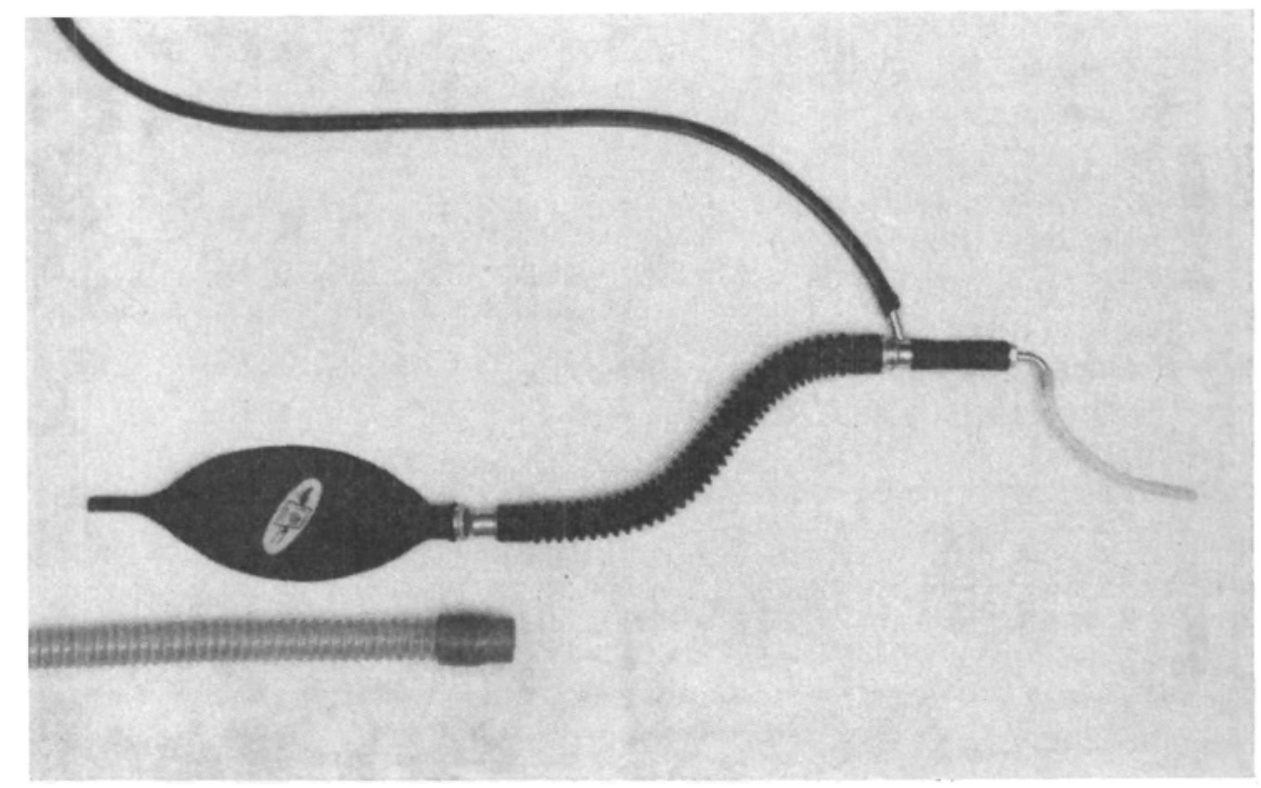

Figure 1. The Jackson-Rees modification of the T-piece, with bag detached. The nonexpansile hose from the ventilator was attached directly to the end of the T-piece.

\footnotetext{
'Presented in condensed form at the Annual Meeting of the Canadian Anaesthetists' Society at Banff, June 6 to 10, 1966. Work supported in part by Dominion-Provincial Grant no. 606-7-92.

tDepartment of Anaesthesia, The Children's Hospital of Winnipeg, Winnipeg, Manitoba.
} 
the advantages of manual inflation, which can deliver gases to the infant at very rapid rates with adjustable pressures and flow rates; and that it must be convenient to use, without pulling heavily on tiny endotracheal tubes and connectors.

This paper deals with the performance of a comparatively new ventilator, the "Ohio DeLuxe," which on preliminary trials had given promise; it is compared here with manual inflation using the Jackson Rees modification.

\section{Material and Methods}

Newborn infants and children were studied during the course of surgery. Table I shows the ages of these patients and the surgery performed.

The paediatric bellows was used on the Ohio DeLuxe ventilator. This machine can be described as volume controlled, pressure limited, i.e. both volume (from 10 to $275 \mathrm{ml}$.) and pressure (up to $40 \mathrm{~mm} . \mathrm{H}_{2} \mathrm{O}$ ) can be preset, and a timer adjustment allows respiratory rate to be altered at will up to 100 cycles per minute. However, a rate as rapid as this is only possible when very small volumes (e.g. $50-70 \mathrm{ml}$ ) are delivered at very rapid flow rates (e.g. a setting of $50 \mathrm{~L} . / \mathrm{min}$. inspiratory flow rate). The mechanical and clinical characteristics of this machine have been well described by Fairley and Hunter. ${ }^{4}$

TABLE I

Ages of Patients and Operations Performed

\begin{tabular}{|c|c|c|c|c|}
\hline & Age & $\begin{array}{l}\text { Weight } \\
\text { (lbs.) }\end{array}$ & Operation & $\begin{array}{l}\text { No. of } \\
\text { cases }\end{array}$ \\
\hline \multirow{2}{*}{\multicolumn{2}{|c|}{$\begin{array}{cl}1 & \text { day } \\
1 & \text { day } \\
1 & \text { day } \\
1 & \text { day } \\
5 & \text { days } \\
5 & \text { weeks and } \\
& 2 \text { years } \\
2 & \text { years } \\
2 & \text { years } \\
21 & \text { to } 6 \text { years } \\
5 & \text { years } \\
10 & \text { years }\end{array}$}} & $\begin{array}{l}8 \\
7 \\
7 \\
7 \\
7\end{array}$ & $\begin{array}{l}\text { meningocele } \\
\text { T-E fistula } \\
\text { anal atresia } \\
\text { uterine cyst } \\
\text { lymphangioma of scrotum }\end{array}$ & $\begin{array}{l}1 \\
1 \\
1 \\
1 \\
1\end{array}$ \\
\hline & & $\begin{array}{c}8,25 \\
29 \\
30 \\
35-44 \\
41,45 \\
45\end{array}$ & $\begin{array}{l}\text { bilateral inguinal hernia } \\
\text { kidney biopsy } \\
\text { cleft palate } \\
\text { tonsillectomy and adenoidectomy } \\
\text { bilateral otoplasty } \\
\text { spinal fusion }\end{array}$ & $\begin{array}{l}2 \\
1 \\
1 \\
6 \\
2 \\
1\end{array}$ \\
\hline \multicolumn{4}{|c|}{ Total number of patients } & 18 \\
\hline
\end{tabular}

\section{Premedication and Anaesthesia}

Meperidine $0.5 \mathrm{mg} . / \mathrm{kg}$. was given to children over $10 \mathrm{~kg}$. body weight, together with atropine in doses of $0.3 \mathrm{mg}$. for children under three years of age and $0.4 \mathrm{mg}$. for older children. Neonates and infants were given atropine $0.2 \mathrm{mg}$. only.

Cyclopropane and halothane were used for induction, succinylcholine was used for endotracheal intubation, and anaesthesia was maintained with equal volumes of nitrous oxide and oxygen with minimal halothane; respiration was controlled by intermittent intravenous injections of succinylcholine.

-Ohio 300 D/O Ventilator, supplied through the courtesy of Mr. G. V. Schlitzer of the Ohio Chemical Company. 
Respiration was controlled manually using the Jackson Rees modification of the T-piece, and when the ventilator was to be used the bag was simply removed and the rigid hose from the machine attached. This hose is non-expansile, but the usual expiratory limb of the $\mathrm{T}$-piece, though made of corrugated rubber, does distend with internal pressure (Fig. 1), a factor of considerable importance here.

Flow patterns were recorded by pneoumotachometer inserted between endotracheal tube and T-piece, tidal volume being derived by electronic integration of the flow curve. An infrared analyser, calibrated according to the method described by Severinghaus, ${ }^{6}$ was used to monitor carbon dioxide concentrations in expired and inspired gases: the sampling catheter was inserted into the tubing close to the endotracheal tube. The whole experimental set-up is schematically shown in Figure 2.

A Beckman (Type R) Dynograph was used for recording and paper write-out. In this way a continuous record was made of percentages of carbon dioxide in expired and inspired gases, while respiratory rate and gas flows from the anaesthetic machine were varied.

The loss of gas in the system due to compression of gas and distensibility of the tubing was measured according to the method recommended by the manufacturers: by occluding the end of the endotracheal tube and noting the contraction of the bellows at preset pressures.
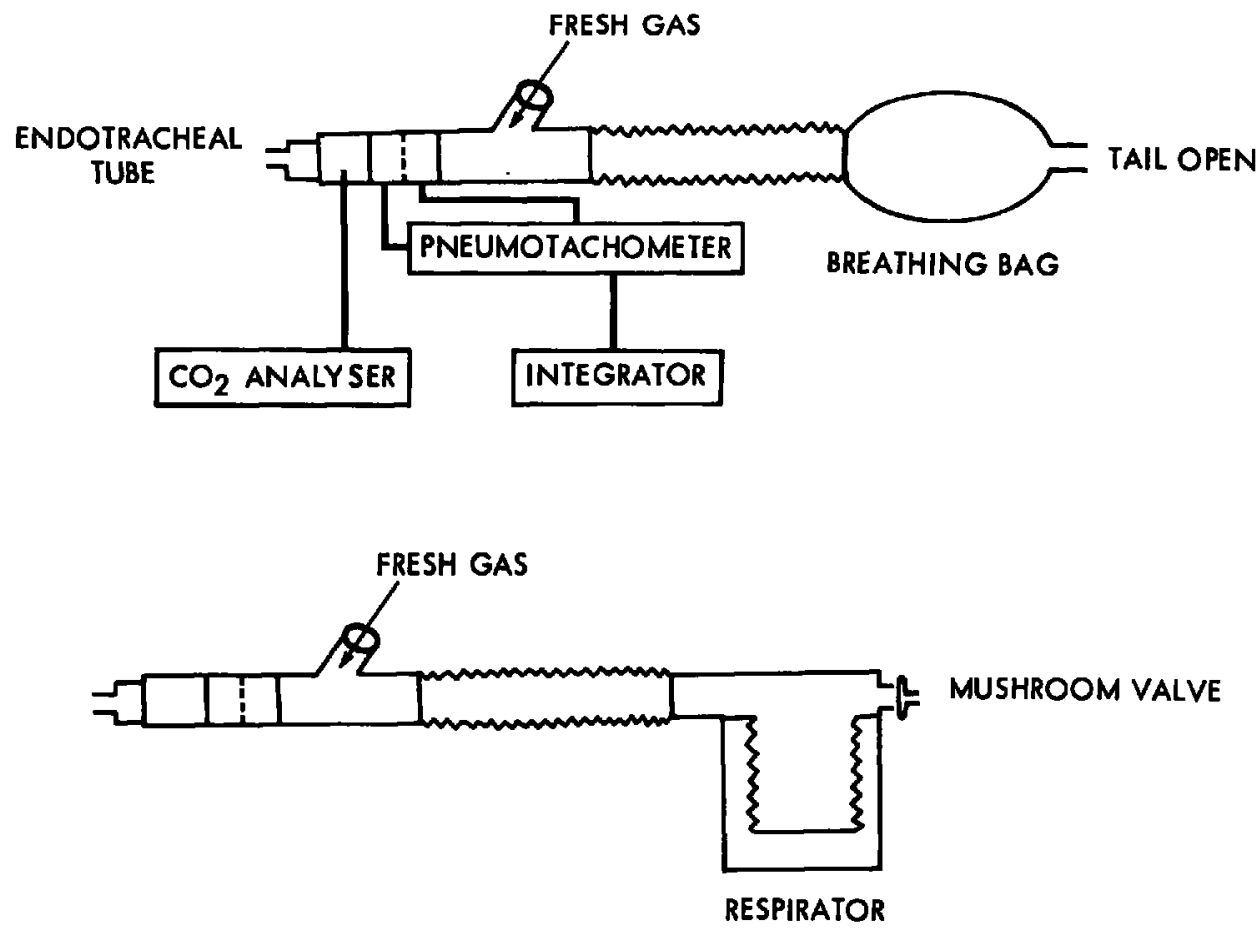

Figure 2. Above: The experimental set-up, with the Jackson-Rees attachment. Below: Ventilator attached to the T-piece. 


\section{Results and Discussion}

The most revealing fact from the work of Nightingale et $a l^{3}$ was that hyperventilation was achieved even in presence of rebreathing.

\section{Effect of Changing Rate of Respiration}

Figure 3 shows that rebreathing was less at 30 cycles per minute than at 60 cycles per minute, but that in both cases the machine caused less rebreathing than the hand.

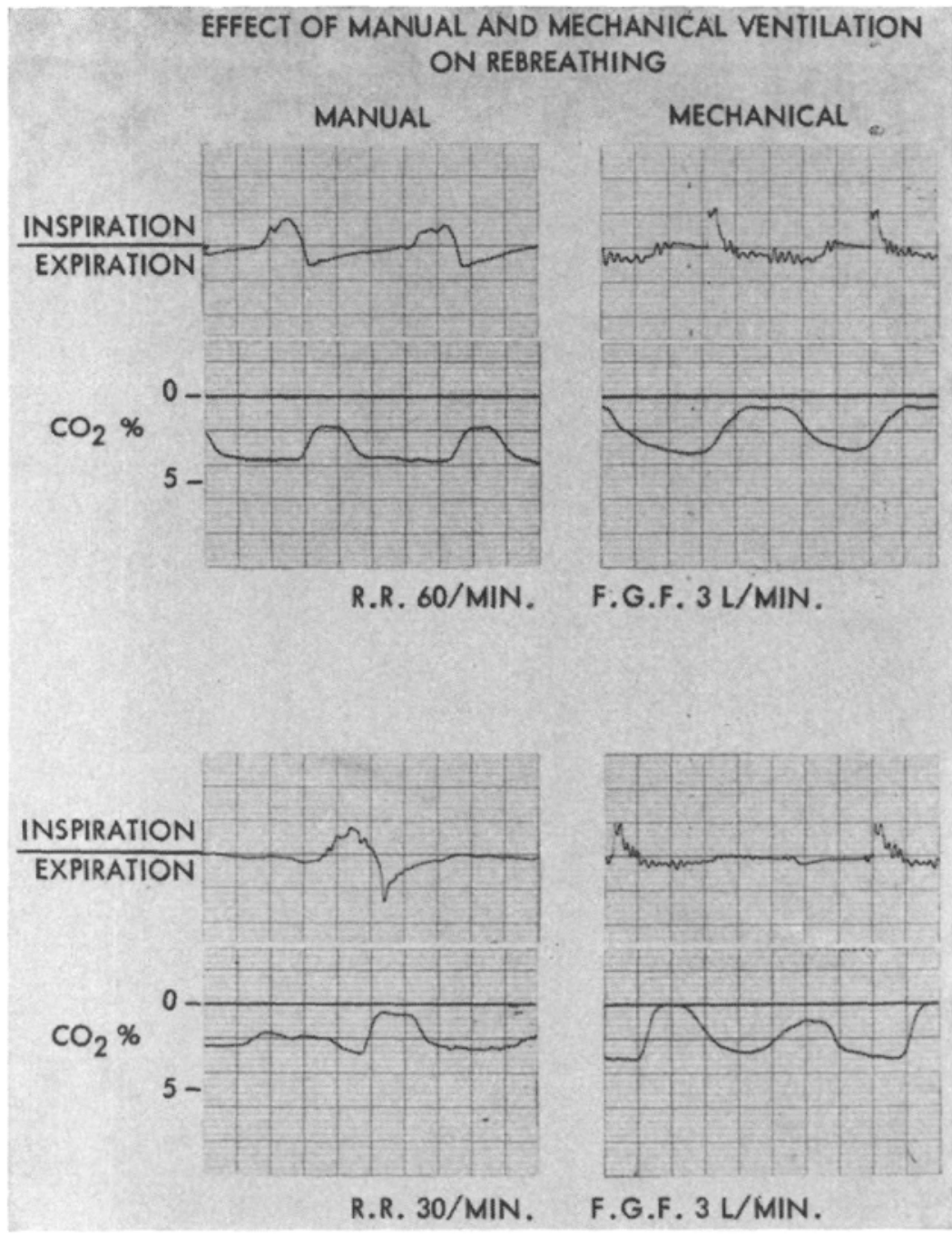

FIGURE 3. Note that inspired carbon dioxide is lower and rebreathing therefore less with mechanical than with manual ventilation. Rebreathing is also less at lower respiratory rates with both mechanical and manual ventilation. Bottom right-hand tracing shows one spontaneous respiration between two mechanical inflations. 
Tables II and III show the results of arterial blood gas studies in patients ventilated mechanically. Even though almost all these patients had some degree of rebreathing, hyperventilation was achieved and was rather more marked in the neonate.

An approximate figure of $150 \mathrm{ml} . / \mathrm{lb}$. body weight per minute appears adequate for fresh gas flow, though probably never less than $3 \mathrm{~L} . / \mathrm{min}$. should be used.

The effect of changing both fresh gas flow and respiratory rate, using both mechanical and manual ventilation, is shown in Figure 4. Higher rates led to more rebreathing, as did lower fresh gas flows. It is of interest that a fresh gas flow of $3 \mathrm{~L} . / \mathrm{min}$. in one infant on the respirator caused no rebreathing at all.

An attempt was made to compare the degree of rebreathing in manually ventilated and mechanically ventilated patients at similar fresh gas flows and respiratory rates. Table IV shows results which favour the ventilator as causing significantly less rebreathing than the hand.

\section{Loss of Gas from Compression and Distension}

Figure 5 shows the loss of effective ventilating volume at different pressures. In this respect the surface area of corrugated tubing is important: more precisely, the actual surface area of the tubing, which is stretched by the distending gas pressure, is a significant determining factor. This surface area is a function of the length of the tubing and its diameter, which are not rigidly standardized in the popular M.I.E. sets. The unit used for the findings in Figure 5 had an internal diameter of $1.7 \mathrm{~cm}$. and was $27 \mathrm{~cm}$. in length. The importance of this distensibility is very great in the neonate.

\section{Required Volume Setting on the Ventilator}

The lip-service paid to the Radford nomogram is usually nullified by the correction factors which most anaesthetists admit to using. Generally we used a bellows volume of three and a half to four times the body weight in pounds. Table II shows that the setting for the neonate has to be higher than this; the distension of the corrugated tubing and consequent loss of effective tidal volume is relatively great at these low volumes and high pressures. A minimum setting of $50 \mathrm{ml}$. is advisable.

\section{Flow Pattern and Resistance to Expiration}

Expiratory flow is somewhat faster with manual ventilation than with the machine (Fig. 3), and the pressure quickly returns to atmospheric if the bag does not become too distended. The adjustment on the ventilator to increase the rate of expiratory flow has very little effect, as noted by Fairley and Hunter. ${ }^{4}$ In addition to the slower expiratory flow rate with the ventilator it was common to find that the recorded pressure at the machine-head did not return quite to zero at the end of expiration. At much higher flows than we need, 1 to $2 \mathrm{~cm} . \mathrm{H}_{2} \mathrm{O}$ positive pressure could be observed, as the mushroom valve at the machine could not quite cope with the flow. Generally a positive pressure of less than $1 \mathrm{~cm}$. $\mathrm{H}_{2} \mathrm{O}$ was seen, and no ill effects on the cardiovascular system were noted. 


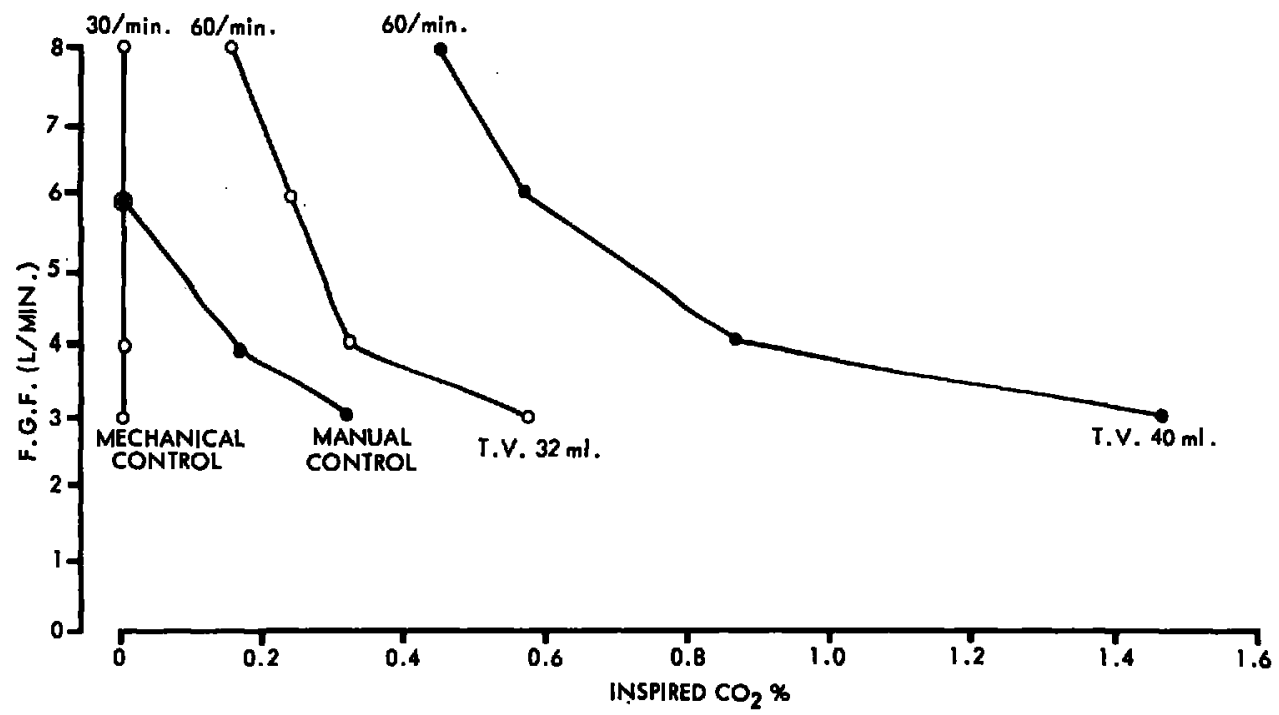

Fxcure 4. Effect of changing fresh gas flow and respiratory rate on rebreathing, using manual and mechanical ventilation.

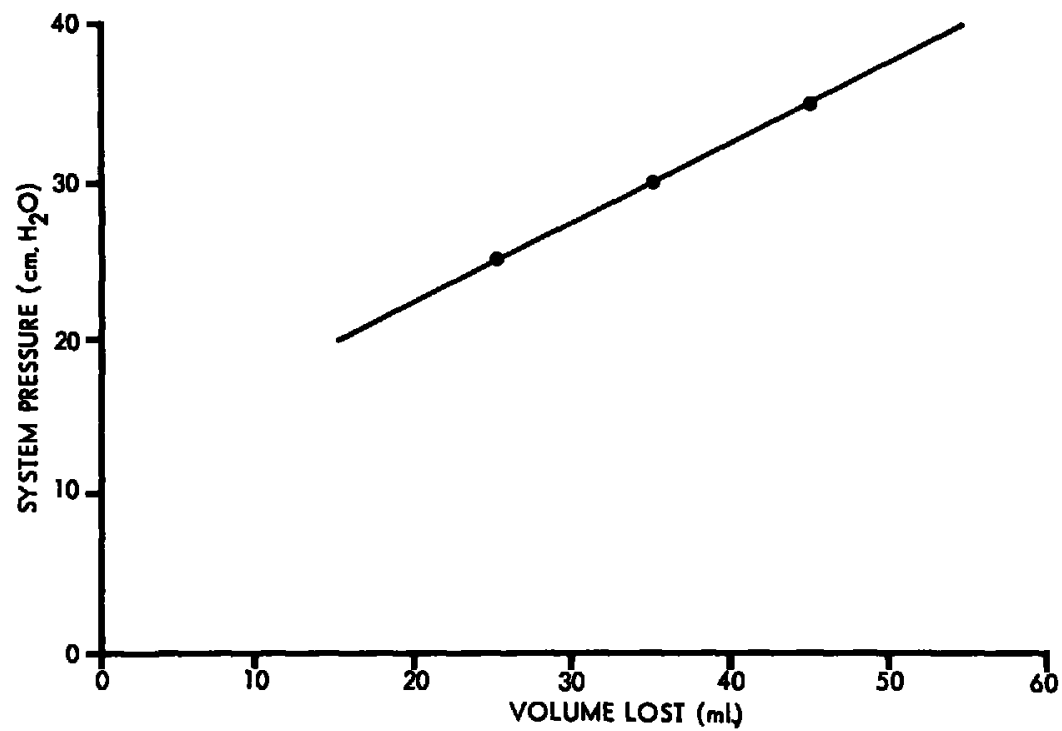

Frgure 5. Loss of effective ventilating volume at different pressures with T-piece and with ventilator. This is the effect of the distensibility of the tubing and the compressibility of the gases. 
TABLE II

Arterial Blood Gases in Neonates with Mechanical Ventilation

\begin{tabular}{|c|c|c|c|c|c|c|c|c|c|c|}
\hline Patient & $\begin{array}{c}\text { Age } \\
\text { (days) }\end{array}$ & $\begin{array}{c}\text { Weight } \\
\text { (lbs) }\end{array}$ & $\underset{(\mathrm{L} . / \mathrm{min} .)}{\text { F.G.F. }}$ & $\underset{\left(\mathrm{cm} . \mathrm{H}_{2} \mathrm{O}\right)}{P}$ & $\begin{array}{l}\text { Bell. } \\
\text { vol. } \\
\text { (ml.) }\end{array}$ & $\begin{array}{l}\text { Resp. } \\
\text { rate }\end{array}$ & pH & $\mathrm{P}_{\mathrm{CO}_{2}}$ & $\mathbf{P}_{\mathrm{O}_{2}}$ & $\begin{array}{c}\text { Dura- } \\
\text { tion } \\
\text { (min.) }\end{array}$ \\
\hline $\begin{array}{l}\text { B.G. } \\
\text { T.W. } \\
\text { G.M. } \\
\text { D.P. } \\
\text { B.B. }\end{array}$ & $\begin{array}{l}1 \\
1 \\
1 \\
5 \\
1\end{array}$ & $\begin{array}{l}7 \frac{3}{4} \\
8 \\
7 \frac{1}{2} \\
7 \\
7 \frac{1}{8}\end{array}$ & $\begin{array}{l}6 \\
4 \\
3 \\
4 \\
4\end{array}$ & $\begin{array}{l}32 \\
29 \\
30 \\
20 \\
25\end{array}$ & $\begin{array}{l}80 \\
50 \\
60 \\
50 \\
50\end{array}$ & $\begin{array}{l}52 \\
43 \\
60 \\
60 \\
60\end{array}$ & $\begin{array}{c}7.46 \\
7.42 \\
7.48 \\
7.50\end{array}$ & $\begin{array}{l}28.0 \\
15.0 \\
30.5 \\
30.5 \\
26.5\end{array}$ & $\begin{array}{r}\overline{-} \\
\overline{82} \\
100\end{array}$ & $\begin{array}{l}20 \\
60 \\
20 \\
15 \\
15\end{array}$ \\
\hline
\end{tabular}

F.G.F. = Fresh gas flow. Bell. vol. = Setting of bellows volume. P. = Pressure at the machine.

TABLE III

Arterial Blood Gases in Older Children with Mechanical Ventilation

\begin{tabular}{|c|c|c|c|c|c|c|c|c|c|c|}
\hline Patient & $\begin{array}{c}\text { Age } \\
\text { (yrs.) }\end{array}$ & $\begin{array}{c}\text { Weight } \\
\text { (lbs.) }\end{array}$ & $\begin{array}{c}\text { F.G.F. } \\
\text { (L./min.) }\end{array}$ & $\begin{array}{c}\mathrm{P} . \\
\left(\mathrm{cm} \cdot \mathrm{H}_{2} \mathrm{O}\right)\end{array}$ & $\begin{array}{l}\text { Bell. } \\
\text { vol. } \\
\text { (ml.) }\end{array}$ & $\begin{array}{c}\text { Resp. } \\
\text { rate }\end{array}$ & pH & $\mathrm{PCO}_{2}$ & $\mathbf{P}_{\mathrm{O}_{2}}$ & $\begin{array}{c}\text { Dura- } \\
\text { tion } \\
\text { (min.) }\end{array}$ \\
\hline $\begin{array}{l}\text { C.S. } \\
\text { J.M. } \\
\text { B.C. } \\
\text { A.W. } \\
\text { M.K. } \\
\text { A.S. } \\
\text { L.F. }\end{array}$ & $\begin{array}{c}4 \\
6 \\
5 \\
5 \frac{3}{2} \\
2 \frac{1}{7} \\
6 \\
10\end{array}$ & $\begin{array}{l}38 \\
44 \\
41 \frac{1}{2} \\
43 \\
35 \\
37 \\
44\end{array}$ & $\begin{array}{l}6 \\
8 \\
6 \\
6 \\
6 \\
6 \\
6\end{array}$ & $\begin{array}{l}24 \\
21 \\
23 \\
22 \\
26 \\
23 \\
25\end{array}$ & $\begin{array}{l}150 \\
175 \\
175 \\
175 \\
130 \\
125 \\
225\end{array}$ & $\begin{array}{l}24 \\
24 \\
24 \\
24 \\
24 \\
24 \\
26\end{array}$ & $\begin{array}{l}7.41 \\
7.47 \\
7.34 \\
7.34 \\
7.34 \\
7.34 \\
7.48\end{array}$ & $\begin{array}{l}35.5 \\
35.3 \\
41.5 \\
40.5 \\
39.2 \\
45.5 \\
30.8\end{array}$ & $\begin{array}{l}250 \\
250 \\
250 \\
175 \\
134 \\
265 \\
260\end{array}$ & $\begin{array}{l}15 \\
20 \\
20 \\
10 \\
20 \\
10 \\
30\end{array}$ \\
\hline
\end{tabular}

Symbols as in Table II.

TABLE IV

End Tidal and Minimum Instired $C_{0_{2}}$ During Manual and Mechanical Ventilation

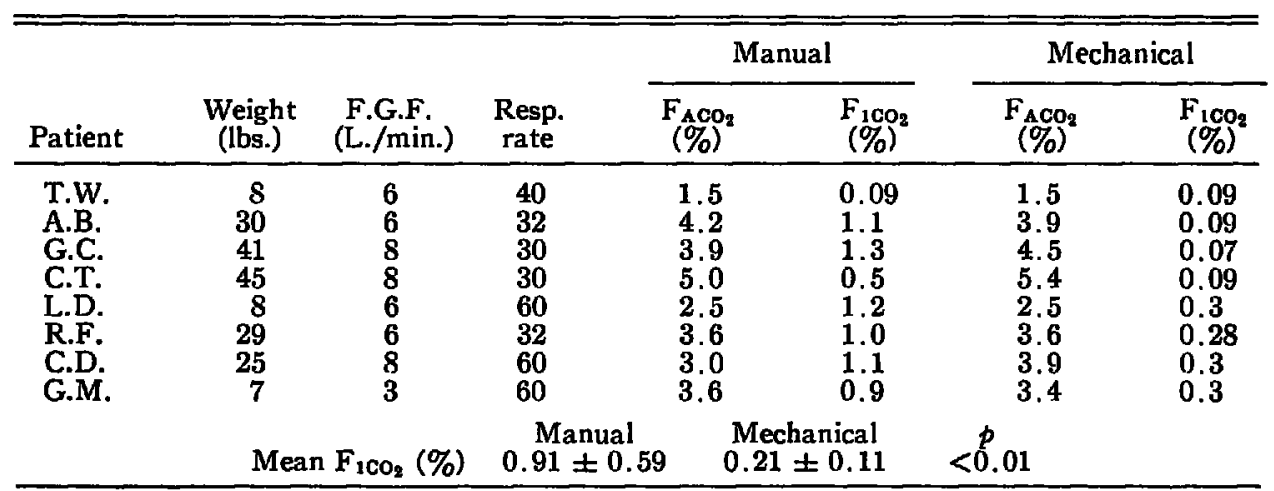

$\mathrm{F}_{\mathrm{AOO}_{2}}=$ Alveolar $\mathrm{CO}_{2} \cdot \mathrm{F}_{\mathrm{tCO}}=$ Minimum inspired $\mathrm{CO}_{2}$. 


\section{Concuustons}

Rebreathing is common and can be accepted with the T-piece when respiration and therefore minute volume is controlled; in fact, lower fresh gas flows can be used than are considered safe with spontaneous respiration, although perhaps Nightingale's figure of $100 \mathrm{ml} . / \mathrm{lb}$. body weight is on the low side. ${ }^{3}$ Certainly $3 \mathrm{~L}$./min. seems a prudent minimum.

The fact that more rebreathing occurs with the Jackson Rees' modification than with the ventilator employed here is probably a reflection of the fact that the bag contains an accumulation of expired air which does readily escape through the open end. In any case good hyperventilation, as shown by arterial carbon dioxide tension, can be achieved either by hand or by machine.

We found the ventilator very useful and effective for controlled respiration with the T-piece, even in small infants. The manufacturers might simplify the dial further by removing both the expiratory flow rate adjustment which is ineffectual, and the assistor and assistor-controller settings, which are inappropriate to its use on the small infant at any rate. For reasons described above it would also be better to change the calibrations on the bellows so that a minimum volume of $50 \mathrm{ml}$. is shown. Fairley and Hunter ${ }^{4}$ have pointed out that it is not strictly accurate to have the calibrations on the inspiratory flow rate dial marked in litres. per second.

\section{SUMMARY}

A comparison has been made between the Ohio DeLuxe ventilator with paediatric bellows, and manual control of respiration with the T-piece technique in infants and small children undergoing surgery. Although rebreathing is common when controlled respiration is used with the T-piece in this way, hyperventilation can still be achieved by raising minute volume. Rebreathing is less. with slower respiratory rates and significantly less with the ventilator than the hand.

Lowering the fresh gas flow increases the degree of rebreathing: $150 \mathrm{ml} . / \mathrm{lb}$. body weight per minute appears adequate with a lower limit of $3 \mathrm{~L} . / \mathrm{min}$. Loss of effective tidal volume due to distension of tubing in the T-piece can be very important, especially in the newborn, where the bellows setting should never be less than $50 \mathrm{ml}$. Generally a setting of four times the body weight in pounds is adequate for older children. This ventilator is convenient and effective to use with the T-piece, even in small infants.

\section{RÉSUMÉ}

Nous avons essayé cliniquement sur des malades allant du nouveau-né à l'âge de 10 ans un système de tube en $T$ modifié rattaché au ventilateur Ohio 300/DO (accordéon pédiatrique). Le fonctionnement mécanique du ventilateur à été étudié a fond par Fairley et ses associés dans leur laboratoire. L'étude actuelle a pour but de comparer l'effet de la ventilation mécanique et de la ventilation manuelle sur la réinspiration en employant ce ventilateur. 
Après une prémédication ordinaire à la mépéridine et a l'atropine chez les enfants et à l'atropine seule chez les nourrissons, nous avons fait l'induction au cyclopropane et avons pratiqué l'intubation. Nous avons maintenu l'anesthésie soit a l'halothane, protoxyde et oxygène ou protoxide, oxygène et succinylcholine en utilisant le système de tube en T modifé. La modification consiste en ceci: le ventilateur a été rattaché sur le côté expiratoire en enlevant le ballon du système. Nous avons enregistré l'allure du courant par un pneumotachomètre. Nous avons mesuré l'air courant en insérant un tracé électronique du débit. Nous avons mesuré le taux de $\mathrm{CO}_{2}$ dans l'air inspiré par un analyseur à rayons infrarouges. Les analyses des gaz dans le sang artériel ont été faites sur des échantillons prélevés dans l'artère radiale.

Nous avons évalué l'efficacité relative de la ventilation mécanique et de la ventilation manuelle avec le plus grand débit de gaz frais (FGF) avec lequel la réinspiration a lieu. La différence a été incontestablement en faveur de la ventilation mécanique si l'on en juge par les taux de $\mathrm{CO}_{2}$ dans l'air inspiré. La respiration contrôlée manuellement a entraîné une plus grande réinspiration que la ventilation mécanique qu'elle soit faite à un rythme lent $(30 / \mathrm{min}$.) ou à un rythme rapide (60/min.) ainsi que le démontre le taux élevé de $\mathrm{CO}_{2}$ dans l'air inspiré. Si l'on diminue le rythme respiratoire, la réinspiration diminue également aussi bien au cours de la ventilation mécanique qu'au cours de la ventilation manuelle.

Dans la pratique de l'anesthésie du nouveau-né, il faut attacher de l'importance a la perte de l'atmosphère anesthésique et à l'expansion des tubes corrugés. D'après notre expérience avec le ventilateur, pour assurer la ventilation adéquate du nouveau-né, il faut fixer l'accordéon à environ $50 \mathrm{ml}$.

D'après les études des gaz du sang et des taux de $\mathrm{CO}_{2}$ à la fin de l'air inspiré, nous sommes d'avis qu'il faut un débit de $150 \mathrm{ml}$./livres de poids pour éviter une réinspiration trop considérable, mais le volume par min. ne doit pas être inférieur à $3 \mathrm{~L} . / \mathrm{min}$. Même avec une réinspiration d'un taux de 1 pour cent de $\mathrm{CO}_{2}$, il a été possible de maintenir un taux de $\mathrm{CO}_{2}$ dans le sang artériel normal ou inférieur à la normale. Nous avons réalisé ce fait en augmentant la ventilation minute pour compenser pour la réinspiration.

La ventilation manuelle est bien efficace à ce point de vue là comme le démontrent les taux de $\mathrm{CO}_{2}$ à la fin de l'expiration, mais la ventilation mécanique en utilisant le système de tube en $T$ est plus fiable et diminue la réinspiration.

\section{REFERENCES}

1. Mapleson, W. W. Theoretical Considerations of the Effects of Rebreathing in Two Semi-closed Anaesthetic Systems. Brit. Med. Bull. 14: 64 (1958).

2. Harrison, G. A. The Effect of the Respiratory Flow Pattern on Rebreathing in a T-piece System. Brit. J. Anaesth. 36: 2061 (1964).

3. Nichtingace, D. A.; Rucharms, G. C.; \& Glass, A. An Evaluation of Rebreathing in a Modified T-piece System during Controlled Ventilation of Anaesthetized Children. Brit. J. Anaesth. 37: 762 (1965).

4. Falmuey, H. B. \& Hunter, D. D. Mechanical Ventilation: An Assessment of Two New Machines for Use in the Operating Room. Canad. Anaesth. Soc. J. 10: 364 (1963).

5. Severingeraus, J. W.; Larson, C. P.; \& Eger, E. Correction Factors for Infrared Carbon Dioxide Pressure Broadening by Nitrogen, Nitrous Oxide, and Cyclopropane. Anesthesiology. 22: 429 (1961). 